the nucleus. The nucleus is represented by a potential with an imaginary part which represents absorption of the neutron. Adjustment of the depth, the radius (which is assumed to vary as $A^{1 / 3}$ ) and the absorption enables a very good fit to be obtained over the entire range of energy and mass. It may be possible to interpret the absorption in terms of the formation of a compound nucleus. The last paper was by C. Goodman (Massachusetts Institute of Technology), who presented some evidence of nuclear excitation by the electrostatic field of an incident proton.

Philip Stehle

\section{AMERICAN AID FOR SCIENTIFIC AND INDUSTRIAL RESEARCH IN GREAT BRITAIN}

$F^{\mathrm{C}}$

URTHER details of the proposed expenditure on advisory service, research and on education and training of the Counterpart Funds derived from United States Economic Aid under the Mutual Security Act of 1952, originally outlined in Cmd. 8776 of February 25, 1953, are given in a White Paper dated July 1953 (Programme of Expenditure of Counterpart Funds derived from United States Economic Aid. Cmd. 8918. Pp. 8. H.M.S.O. 4d. net). Under "Advisory Service", $£ 25,000$ goes to the Department of Scientific and Industrial Research for the development of advisory services in industrial engineering, and in the use of measurement techniques developed in the National Physical Laboratory, and a further $£ 125,000$ for assistance to research associations (in conjunction with trade associations where suitable) for the development or initiation of advisory services. A number of trade and employers' associations will receive grants totalling $£ 72,000$ in all to enable them to employ consultants on such subjects as cost accounting, factory lay-out and organization and the deployment of labour. The Ministry of Works receives $£ 20,000$ for the development of the Building Advisory Service, and the Ministry of Labour and National Service $£ 15,000$ for assistance to voluntary organizations developing advisory services to industry in the field of training. Agricultural departments will receive $£ 116,500$ for the extension or initiation of specific advisory services, and the British Institute of Management $£ 35,000$ for research and the preparation and provision of information of management subjects of importance to productivity and for the extension of the Institute's information and research departments.

Of $£ 589,500$ provisionally allocated for research, $£ 210,000$ goes to a programme of economic research based in part on proposals put forward by universities and research organizations. It includes $£ 42,000$ for studies of general factors affecting productivity and the adoption of innovations ; $£ 100,000$ for studies in monopoly, competition and restrictive practices, including studies in the structure of selected industries; $£ 25,000$ for studies in the growth of capital and the finance of industry; $£ 8,000$ for studies of economic problems affecting labour recruitment and mobility; $£ 11,000$ for studies in economic problems of transport and $£ 19,000$ for studies in the statistical measurement of production. The programme of research in production economics, for which $£ 75,000$ is allocated, will be carried out under the ægis of the Department of Scientific and Industrial Research by research associations and other bodies. It will include studies of the innovation and development of new ideas; of the flow of scientific and technical information to industry and its relation to innovation and industrial efficiency; of the economics of re-equipment ; and of the measurement of productivity and the causes of variation of industrial efficiency.

The programme of social research, for which $£ 190,000$ is allocated, will be planned and co-ordinated by the two Committees on Human Relations in Industry and Industrial Efficiency recently set up by the Lord President of the Council. It includes $£ 20,000$ for studies of the influence of equipment design and working conditions on the efficiency of operators; $£ 15,000$ for studies of factors affecting the efficient utilization of industrial engineering techniques; $£ 30,000$ for studies of factors influencing the effectiveness of incentive payment schemes ; and $£ 40,000$ for studies of those restricting and facilitating the introduction of new production techniques and methods in industry; $£ 30,000$ for studies of the characteristics of management organizations influencing productivity; $£ 10,000$ for studies of factors facilitating the efficient utilization of university graduates in industry; and $£ 25,000$ for studies of promotion and training in industry. The allocation of $£ 114,500$ for research in agricultural subjects includes $£ 8,000$ each for studies in land ownership and in land economics; $£ 25,000$ for a survey of prevalence, etc., of livestock diseases, and $£ 22,500$ for studies of egg-and table-poultry production.

Of the $£ 519,000$ provisionally allocated for education and training, $£ 290,000$ is for the endowment of three university chairs or readerships in engineering and related subjects. It is hoped that one in heavy electrical engineering and another in production engineering will be at the Imperial College of Science and Technology, London. The $£ 130,000$ for technical education is for the creation of teaching posts in industrial engineering and the provision of scholarships in methods of engineering, work study and personnel management. Of $£ 68,000$ to agricultural departments, $£ 25,000$ is for postgraduate scholarships and a like sum for managerial and special courses for staffs of Co-operatives, $£ 18,000$ is for assistance to Scottish crofters, $£ 20,000$ is provided towards the development of engineering training facilities at Queen's University, Belfast, and the Belfast College of Technology, and $£ 6,000$ to the Department of Scientific and Industrial Research towards technical and management training in the cast iron industry.

The allocation for publicity includes $£ 22,400$ for publications, chiefly to the Department of Scientific and Industrial Research for the preparation of technical digests of articles appearing in the technical press, and the preparation of brochures on technical information services; and to research associations for the preparation of technical publications. An allocation is also being made to the Ministry of Works for the preparation of technical publications giving the results of scientific research and new developments in building. One million pounds has been allocated to the Revolving Loan Fund, $£ 700,000$ for loans to industry and $£ 300,000$ for loans to agriculture; advisory committees have been set up for each part of the fund. The types of loan likely to be approved and the conditions which will be attached to them will be announced by the committee for industry, of which Sir John Woods is chairman. Loans to agriculture (of which committee Sir Stanford Cooper is chairman) will be confined in the first instance to 
two main purposes : the provision of part of the approved capital cost of acquisition and installation of grain-drying equipment and storage facilities ; and assistance in the provision of plant, equipment and working capital for agricultural co-operative societies and other approved associations of farmers.

\section{AMERICAN PHILOSOPHICAL SOCIETY} YEAR BOOK FOR 1952

$\mathrm{T}$ HE year book for 1952 of the American Philosophical Society* includes a brief history of the Society and a copy of the charter, together with the list of members and the customary obituary notices and list of publications during the year; besides this it gives, in the report of the committee on research, lists of grants made during the year January 1December 31, 1952, from the three research funds administered by the Society as follows: from the Penrose Fund, which is unrestricted, 133 grants totalling 123,250 dollars; from the Johnson Fund, nine grants totalling 20,687 dollars; and from the Daland Fund, which is limited to research in clinical medicine, three grants totalling $\mathbf{3 , 7 5 0}$ dollars. Brief reports from recipients of grants, arranged alphabetically by sciences, are also included. Among the longer of these summaries may be mentioned those of the following: M. D. Taylor on the vapour-phase dissociation of formic, propionic and acetic acids, indicating that formic acid possesses by far the weakest hydrogen bond, acetic and propionic acids possessing bonds of nearly equal strength; R. W. Chaney, comparing the Cenozoic floras of Japan with those of corresponding age in North America, and indicating that Metasequoia was widely distributed and abundant at high northern latitudes during Cretaceous and Tertiary time; H. P. Hansen on his investigation of post-glacial forest migrations and climate in western Canada and Alaska by means of pollen analysis of peat sections ; R. J. Drake on a study of the species (and distribution) of the nonmarine molluse fauna of Sonora (Mexico); W. B. Jackson on microclimatic factors in army ant behaviour and ecology; and A. Loveridge on ecological studies on the vanishing fauna of rainforest remnants in tropical East Africa. F. A. McDermott reports further data on Jamaican Lampyridæ, M. C. Carlsen on plant collecting in southern Mexico and Honduras, $\mathbf{H}$. A. Imshaug on a taxonomic and phytogeographic study of the lichen flora of the Rocky Mountains, Hui-Lin Li on a study of the Scrophulariace of China, H. E. Moore, jun., on native and cultivated palms of the western hemisphere, and H. T. Skinner on character patterns in the Amorican azaleas.

K. J. Hayes records an analysis of chimpanzee intelligence, and in biochemistry J. L. and E. M. Irvin report on their spectrophotometric study of the interaction of quinoline and acridine derivatives with plasma proteins, nucleic acids and nucleoproteins. W. J. Eversole summarizes studies which indicate a physiological role of secretions of the adrenal medullary hormones in water and electrolyte metabolism; G. R. Seaman, metabolic studies on the growth factor protogen; L. S. Crossman, studies

* American Philosophical Society. Year Book, 1952. January 1. 1952-December 31, 1952. Pp. 486+1 plate. (From the Socjety, Philadelphia, Penn., 1953. on the prehistory of the Oregon coast; and M. I. Hilger, an ethnological field study of the beliefs, customs and traditions in the development, rearing and training of the Araucanian Indian child of Chile. Besides E. M. Kampa's investigation of the photosensitive pigments in marine animals in the vicinity of Bermuda, which indicates the observation of at least one new photosensitive pigment, there are briefer reports on eight other investigations by scientists working at the Bermuda Biological Station for Research, including aspects of phosphate metabolism, the luminous bacteria-bacteriophage system, the metabolic effects of sinus gland removal in land Crustacea, the sponges of Bermuda, cell-growth and development as affected by changes in oxidationreduction potential, and parasitological studies of fishes.

\section{STANDARD FREQUENCY TRANSMISSIONS FROM THE UNITED KINGDOM}

CTANDARDS of frequency and time differ from $S$ other standards of measurement in that they can be made available continuously over wide areas by means of radio transmissions. The frequencies of $2 \cdot 5,5,10,15,20$ and $25 \mathrm{Mc}$./s. have, by international agreement, been allocated for this purpose; and for several years past, a continuous service on all these frequencies (and also on 30 and $35 \mathrm{Mc}$./s.) has been operating from station $W W V$ of the National Bureau of Standards, near Washington, D.C.

Such transmissions enable the user to standardize his equipment without costly and elaborate apparatus, but to be fully effective they must be received in all parts of the world. The $W W V$ transmissions do not meet this requirement, and experiments on an international scale are therefore being conducted under the general direction of the International Radio Consultative Committee in order to discover the best means of securing world-wide coverage.

As the United Kingdom's contribution to this work, a limited programme of transmissions has been made daily since February 1950 from the Post Office station at Rugby under the call-sign $M S F$. On May 26 this year the programme was extended to provide a continuous (twenty-four hours a day) service of transmissions on the three frequencies of $2 \cdot 5,5$ and $10 \mathrm{Mc} . / \mathrm{s}$. Later, 15 and $20 \mathrm{Mc} / \mathrm{s}$. may be used, but only three frequencies will be transmitted simultaneously. The signals are identified by a speech announcement made at fifteen-minute intervals, while during five-minute periods the carrier waves are modulated in turn by a 1,000-c./s. tone and by $1-\mathrm{c} . / \mathrm{s}$. pulses, the fifty-ninth pulse in each minute being omitted. A supplementary local service for use within the United Kingdom is also provided by a special transmission at a frequency of $60 \mathrm{kc} . / \mathrm{s}$. for a period of one hour daily.

Full details of these new transmissions are given in a pamphlet issued by the National Physical Laboratory, Teddington, under the title " $M S F-$ New Programme of Experimental Frequency Transmissions from the United Kingdom". The carrier and modulation frequencies are all obtained from the same standard and are maintained within \pm 2 parts in $10^{\circ}$ of their nominal values. The transmissions are regularly monitored at the National Physical Laboratory, and the results of daily measurements on 